\title{
Aqueous complexation reactions governing the rate and extent of biogeochemical $\mathrm{U}(\mathrm{VI})$ reduction \\ 1024827
}

Argonne National Laboratory: K. M. Kemner* and S. D. Kelly (Argonne National Laboratory, Biosciences Division, 9700 South Cass Avenue, Argonne, Illinois, 60439, Kemner@anl.gov (630) 252-1163)

Oak Ridge National Laboratory: Scott C. Brooks*, Wenming Dong, Sue Carroll

Pacific Northwest National Laboratory: James K. Fredrickson.

Research Objective: The proposed research will elucidate the principal biogeochemical reactions that govern the concentration, chemical speciation, and reactivity of the redox-sensitive contaminant uranium. The results will provide an improved understanding and predictive capability of the mechanisms that govern the biogeochemical reduction of uranium in subsurface environments. In addition, the work plan is designed to:

- Generate fundamental scientific understanding on the relationship between U(VI) chemical speciation and its susceptibility to biogeochemical reduction reactions.

- Elucidate the controls on the rate and extent of contaminant reactivity.

- Provide new insights into the aqueous and solid speciation of U(VI)/U(IV) under representative groundwater conditions.

These goals and objectives will be met through a series of hypothesis-driven tasks that focus on (i) the use of well-characterized mineral isolates and natural subsurface mineral assemblages, (ii) advanced spectroscopic techniques to monitor changes in the aqueous and solid-phase speciation of uranium, and (iii) close collaboration between microbiologists, geochemists, and physicists to provide for rigorous design and interpretation of experiments.

Research Progress and Implications: This report summarizes work after two years of a three year project.

Mission Relevance. The experimental and numerical results of this research will quantify the conditions that govern the rate and extent of $\mathrm{U}(\mathrm{VI})$ reduction under representative subsurface conditions. By providing an improved understanding of the competitive processes that affect contaminant reactivity in multicomponent systems, we will enhance the successful application of microbially mediated contaminant stabilization in the field. The enhanced understanding derived from this research will allow for the development of innovative approaches for in situ bioimmobilization of radionuclides at DOE contaminated sites and a better understanding of the requirements for maintaining contaminants as reduced and poorly soluble phases.

Formation of alkaline earth metal-uranium-carbonate ternary complexes. Ternary complexes of $\mathrm{U}(\mathrm{VI}), \mathrm{CO}_{3}{ }^{2-}$, and alkaline earth metals $\left(\mathrm{Mg}^{2+}, \mathrm{Ca}^{2+}, \mathrm{Sr}^{2+}, \mathrm{Ba}^{2+}\right)$ may play an important role in the environmental chemistry of uranium. Despite previous efforts to quantify the formation 
constants for the $\mathrm{Ca}-\mathrm{U}(\mathrm{VI})-\mathrm{CO}_{3}$ complexes, concerns remain and they are not officially recognized in the most recent compilation of $U$ thermodynamic data. We measured the formation constants of ternary complexes $\left(\mathrm{MUO}_{2}\left(\mathrm{CO}_{3}\right)_{3}{ }^{2-}\right.$ and $\left.\mathrm{M}_{2} \mathrm{UO}_{2}\left(\mathrm{CO}_{3}\right)_{3}{ }^{0}\right)$ of uranyl and carbonate with alkaline earth metals $\left(\mathrm{M}^{2+}\right.$ denotes $\mathrm{Mg}^{2+}, \mathrm{Ca}^{2+}, \mathrm{Sr}^{2+}$, and $\left.\mathrm{Ba}^{2+}\right)$ with an anion exchange method by varying the metal concentrations $(0.1-5 \mathrm{mmol} / \mathrm{L})$ at $\mathrm{pH} 8.1$ and a constant ionic strength $\left(0.1 \mathrm{~mol} / \mathrm{L} \mathrm{NaNO}_{3}\right)$ under equilibrium with atmospheric $\mathrm{CO}_{2}$. The results indicate that the complexes of $\mathrm{MUO}_{2}\left(\mathrm{CO}_{3}\right)_{3}{ }^{2-}$ and $\mathrm{M}_{2} \mathrm{UO}_{2}\left(\mathrm{CO}_{3}\right)_{3}$ are simultaneously formed for $\mathrm{Ca}^{2+}$ and $\mathrm{Ba}^{2+}$, while $\mathrm{Mg}^{2+}$ and $\mathrm{Sr}^{2+}$ form only the $\mathrm{MUO}_{2}\left(\mathrm{CO}_{3}\right)_{3}{ }^{2-}$ complex under our experimental conditions.

Influence of EDTA and $\mathrm{pH}$ on Bioreduction of Uranium(VI) in the Presence of Calcium Ions. Previously, we reported that the aqueous $\mathrm{Ca}_{2} \mathrm{UO}_{2}\left(\mathrm{CO}_{3}\right)_{3}{ }^{0}$ complex can effectively inhibit U(VI)

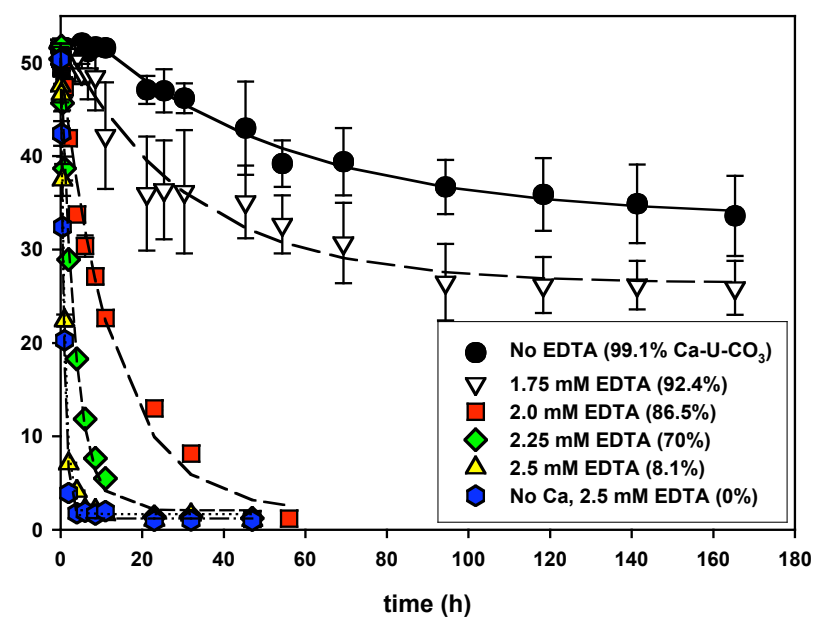

Figure 1 Microbial U(VI) reduction at $\mathrm{pH} 6.5$ as a function of EDTA concentration. As the concentration of EDTA in solution is increased, the fraction of $\mathrm{U}(\mathrm{VI})$ in the $\mathrm{Ca}-\mathrm{U}(\mathrm{VI})-\mathrm{CO}_{3}$ complexes decreases and the rate and extent of $U(V I)$ reduction increases. bioreduction (BROOKS et al., 2003). In this study, the bioreduction of $\mathrm{U}(\mathrm{VI})$ was investigated in the presence of $2.5 \mathrm{mM} \mathrm{Ca}$ and varying EDTA concentration (1.75-2.5 $\mathrm{mM})$ and $\mathrm{pH}(6.5$ and 7.1$)$ under anoxic conditions. The rate and extent of U(VI) bioreduction increased with increasing EDTA concentration (Figure 1). These observations are consistent with decreased $\mathrm{Ca}_{2} \mathrm{UO}_{2}\left(\mathrm{CO}_{3}\right)_{3}{ }^{0}$ concentration due to the competitive complexation of $\mathrm{Ca}^{2+}$ by EDTA. The reduced U(IV) was observed in the forms of uraninite and U(IV)-EDTA complexes in the absence and presence of EDTA, respectively. Faster $\mathrm{U}(\mathrm{VI})$ reduction with increased $\mathrm{pH}$ is consistent with a lower predicted $\mathrm{Ca}_{2} \mathrm{UO}_{2}\left(\mathrm{CO}_{3}\right)_{3}{ }^{0}$ concentration at $\mathrm{pH}$ 7.1. $\mathrm{U}(\mathrm{VI})$ speciation calculation and EXAFS analysis were applied to confirm our hypothesis that aqueous complexation controlled U(VI) bioreduction through the reactions of $\mathrm{Ca}^{2+}$ with $\mathrm{UO}_{2}\left(\mathrm{CO}_{3}\right)_{3}{ }^{4-}$ and EDTA. In addition, $\mathrm{x}$-ray absorption spectroscopy confirmed the formation of U(IV)-EDTA solution complexes.

Effects of $\mathrm{pH}$, EDTA, and $\mathrm{Ca}^{2+}$ on U(IV) oxidation: A method to determine U(IV) from the total uranium and $\mathrm{U}(\mathrm{VI})$ in solutions by laser-induced kinetic phosphorimetry. The effects of $\mathrm{pH}$, EDTA and $\mathrm{Ca}^{2+}$ on the oxidation of biogenic uraninite and U(IV)-EDTA complexes were investigated at acidic and weakly alkaline $\mathrm{pH}$ under atmospheric conditions. The uraninite and U(IV)-EDTA were prepared by the bioreduction of U(VI) in the absence and presence of EDTA and $\mathrm{Ca}^{2+}$ under anaerobic conditions. The results indicate that the oxidation rate of uraninite and $\mathrm{U}(\mathrm{IV})$-EDTA increased with increasing $\mathrm{pH}$ and can be well described with a first-order reaction. In particular, EDTA decreased the oxidation rate at $\mathrm{pH} 1$ and enhanced the oxidation rate at $\mathrm{pH}$ 8.1. At $0.1 \mathrm{M} \mathrm{HNO}_{3}$ medium, the oxidation rate decreased with increasing EDTA concentration, indicating that a treatment of mixed $\mathrm{U}(\mathrm{VI}) / \mathrm{U}(\mathrm{IV})$ samples with the $0.1 \mathrm{M} \mathrm{HNO}_{3}$ and addition of 
appropriate EDTA can effectively inhibit the oxidation of U(IV), suggesting an improved method to determine U(IV) from the difference of U(VI) and total U in KPA.

X-ray absorption spectroscopy identifies calcium-uranyl-carbonate complexes at environmental concentrations. Current research on bioremediation of uranium-contaminated groundwater focuses on supplying indigenous metal-reducing bacteria with the appropriate metabolic requirements to induce microbiological reduction of soluble uranium(VI) to poorly soluble uranium(IV). Recent studies of uranium(VI) bioreduction in the presence of environmentally relevant levels of calcium revealed limited and slowed uranium(VI) reduction and the formation of a $\mathrm{Ca}-\mathrm{UO}_{2}-\mathrm{CO}_{3}$ complex. However, the stoichiometry of the complex is poorly defined and may be complicated by the presence of a $\mathrm{Na}-\mathrm{UO}_{2}-\mathrm{CO}_{3}$ complex. Such a complex might exist even at high calcium concentrations, as some $\mathrm{UO}_{2}-\mathrm{CO}_{3}$ complexes will still be present. The number of calcium and/or sodium atoms coordinated to a uranyl carbonate complex will determine the net charge of the complex. Such a change in aqueous speciation of uranium(VI) in calcareous groundwater may affect the fate and transport properties of uranium. We performed X-ray absorption fine structure (XAFS) measurements of a series of solutions containing $50 \mu \mathrm{M}$ uranium(VI) and $30 \mathrm{mM}$ sodium bicarbonate, with various calcium concentrations of 0-5 $\mathrm{mM}$. Use of the data series reduced the uncertainty in the number of calcium atoms bound to the $\mathrm{UO}_{2}-\mathrm{CO}_{3}$ complex to approximately 0.6 and enabled spectroscopic identification of the $\mathrm{Na}-\mathrm{UO}_{2}-\mathrm{CO}_{3}$ complex. At nearly neutral $\mathrm{pH}$ values, the numbers of sodium and calcium atoms bound to the uranyl triscarbonate species are found to depend on the calcium concentration, as predicted by speciation calculations.

\section{Planned Activities:}

For the final year of this project we plan experiments that will quantify individual and synergistic effects of solution chemistry on bacterial U(VI) reduction. For example, testing the presence of calcium or magnesium alone versus the presence of both alkaline earth elements.

Refine estimate of stability constants for alkaline earth-uranyl-carbonate complexes. Previous research produced equivocal results for some systems. New studies have been designed to reduce these uncertainties.

Quantify effect of alkaline earth elements on abiotic U(VI) reduction processes (e.g., reduction by $\left.\mathrm{AH}_{2} \mathrm{DS}, \mathrm{Fe}(\mathrm{II})\right)$.

Determine the ability of synchrotron x-ray techniques to discriminate between inorganic and organic carbon (bound to uranyl).

Use x-ray absorption spectroscopy to characterize the valence state and local chemical environment of $\mathrm{U}$ sorbed to bacterial cell walls in the presence and absence of $\mathrm{Ca}$.

Collect higher quality U XAFS data of U(IV)-EDTA moiety in solution to better refine the stereochemical interaction between U(IV) and EDTA. 


\section{Information Access:}

Publications

Kelly, S. D., K. M. Kemner, and S. C. Brooks. in press. X-ray absorption spectroscopy identifies calcium-uranyl-carbonate complexes at environmental concentrations. Geochim. Cosmochim. Acta. doi:10.1016/j.gca.2006.10.013

Dong, W. and S. C. Brooks. 2006. Determination of the formation constants of ternary complexes of uranyl and carbonate with alkaline earth metals $\left(\mathrm{Mg}^{2+}, \mathrm{Ca}^{2+}, \mathrm{Sr}^{2+}\right.$, and $\left.\mathrm{Ba}^{2+}\right)$ using anion exchange method. Environ. Sci. Technol. 40(15):4689-4695. doi: 10.1021/es0606327

Kelly, S. D., K. M. Kemner, S. C. Brooks, J. K. Fredrickson, S. L. Carroll, D. W. Kennedy, J. M. Zachara, A. E. Plymale, and S. Fendorf, "Ca-UO2-CO3 complexation- Implications for bioremediation of U(VI)," Physical Scripta T115 915-917, 2005.

Presentations and Published Abstracts

Brooks, S.C., W. Dong, S. L. Carroll, S. D. Kelly, and K. Kemner. 2006. Influence of EDTA and $\mathrm{pH}$ on uranium(VI) bioreduction in the presence of calcium ions. Abstracts of the $231^{\text {st }}$ National Meeting, American Chemical Society, Atlanta, GA, 26-30 March 2006.

Dong, W., S. C. Brooks, S. D. Kelly, K. Kemner, and K. A. Orlandini. 2006. Determination of the formation constants of ternary complexes of uranyl and carbonate with alkaline earth metals $\left(\mathrm{Mg}^{2+}, \mathrm{Ca}^{2+}, \mathrm{Sr}^{2+}\right.$, and $\left.\mathrm{Ba}^{2+}\right)$ by using anion exchange method. Abstracts of the $231^{\text {st }}$ National Meeting, American Chemical Society, Atlanta, GA, 26-30 March 2006.

Dong, W. and S. C. Brooks. 2006. Effects of $\mathrm{pH}$, EDTA, and $\mathrm{Ca}^{2+}$ on oxidation rate of biogenic uraninite and U(IV)-EDTA complexes. Abstracts of the $231^{\text {st }}$ National Meeting, American Chemical Society, Atlanta, GA, 26-30 March 2006.

Brooks, S. C., W. Dong, J. K. Fredrickson, K. M. Kemner, and Shelly D. Kelly. 2005. The Effect of Uranyl-Alkaline Earth Complexes on Bacterial U(VI) Reduction. 2005 International Chemical Congress of Pacific Basin Societies (PACIFICHEM 2005). 15-20 Dec. 2005, Honolulu, Hawaii. INVITED.

B. Ravel, S. D. Kelly, D. Gorman-Lewis, M. I. Boyanov, J. B. Fein and K. M. Kemner, “A pHdependent X-ray Absorption Spectroscopy study of U adsorption to bacterial cell walls", $13^{\text {th }}$ International XAFS Conference, Stanford University, Palo Alto, CA, July 9-14, 2006.

\section{Literature Cited}

Brooks S. C., Fredrickson J. K., Carroll S. L., Kennedy D. W., Zachara J. M., Plymale A. E., Kelly S. D., Kemner K. M., and Fendorf S. (2003) Inhibition of bacterial U(VI) reduction by calcium. Environ. Sci. Technol. 37(9), 1850-1858. 